\title{
General aspects regarding the phenomenon of alcoholism in literature CIOBICA Irina ${ }^{1}$, CIOBICA Alin ${ }^{1,2}$, TIMOFTE Daniel $^{3^{*}}$, COLIBABA Stefan ${ }^{1}$ \\ 1 "Alexandru Ioan Cuza" University, lasi, Romania \\ ${ }^{2}$ Center of Biomedical Research of the Romanian Academy, lasi, Romania \\ 3 "Gr. T. Popa" University of Medicine and Pharmacy, lasi, Romania \\ *E-mail address: dantimofte@yahoo.com
}

Keywords: alcoholism; literature

\begin{abstract}
In this paper we followed the links that are established between alcohol consumption and writing, and especially on how creativity and alcohol consumption are related. Thus, we will discuss the effects of drinking, as demonstrated until now, on the creative flow, and we will try to provide a substantial number of case examples of brilliant creative minds, that had been either diagnosed as being alcoholics or just known to be heavy drinkers. Our article will also comment on the general and particular theories that refer to this much discussed and somewhat controversial subject.
\end{abstract}

\section{INTRODUCTION}

The effects of psychoactive drugs have been closely linked to all forms of art for as long as humans have made contact with their creative side, but it seems that a review of the subject is currently very relevant in works of psychological, literary or even social nature. And this may be in particular the case of alcohol as it has been strongly linked to the creative process.

The interest in the study of the existent links between alcohol and creativity seem to have grown as, setting aside the well-known myth of the 'good artist as a drinking artist', statistics seem to point out in the same direction, as it shows that in America, for example, out of the seven native born Nobel awarded writers, five were diagnosed as being alcoholic.

The pioneering work in the field was done by an Americanist, Roger Forseth, who's careful and provocative studies of writers such as William Faulkner, Scott F. Fitzgerald \& Ernest Hemingway, used close textual analysis of their literary works in the context of the medical model of addiction. His analyses also intertwined the writers' alcoholism with that of the characters in their novels.

Studies of addiction in literature typically approach the subject from a pathological point of view: Donald W. Goodwin's 'Alcohol and the Writer' and Tom Dardis' 'The Thirsty Muse', the two best-known of such works in the last decade, go a long way toward exploring it, in a quest of answering the enigma of why so many modern writers, including the majority of American winners of the Nobel Prize, fact aforementioned, self-indulged in the hands of alcohol and whether or not intoxication played a key role in the development of their literary crafts.

\section{ALCOHOL AND CREATIVITY}

In this way, the psychiatrist Donald W. Goodwin blames Edgar Allan Poe for 'ushering' into America the romantic tradition in which 'writers and poets were expected to be tragic, lonely, and doomed' (183). Indeed, alcohol consumption not only served as an identity marker of the modernist artist, but was also associated with an artist's creative potential. If Poe was the portrait of the artist as a tragic, lonely and alcoholic, William Faulkner, according to the literary critic Thomas Dardis, was the portrait of the alcoholic as modernist, as he 'drank alcoholically for nearly fifty years' and firmly argued that "there is no such thing as bad whiskey. Some whiskeys just happen to be better than others. But a man shouldn't fool with booze until he's fifty; then he's a damn fool if he doesn't." 
In 'Western literary tradition', critic Leslie Fiedler noted that great writers need a flaw, a 'charismatic weakness'. Often that weakness is drinking, the 'writer's vice', as Fitzgerald called it.

But why all these huge artistic names chose to do so? It is possible that their heredity compelled it as the writing ability and alcoholism may have common, partly innate roots, says Goodwin. Or it might be, at least in Fitzgerald's case, as some theories suggest, that talent and alcoholism 'have a common meeting point' with another disorder that may have a genetic source: manic-depressive disease.

While asking the question of whether drinking helped or hindered the careers of the writers that he chose to present, Dr. Donald W. Goodwin, a psychiatrist who has spent 20 years studying alcoholism, reached mixed conclusions, as examples seem to vary.

The connection between addiction and creativity remains as enigmatic and complex as it was for Thomas De Quincey exploring his opium habit almost 200 years ago. Goodwin postulates that the perception most writers have of themselves as loners is what opens the door to their drinking. 'Writing and alcohol both produce trancelike states' he notes. A gift for creative writing may involve an innate ability to enter such states. Being a loner, maybe shy, isolated, without strong personal ties might facilitate these states when it is time to write and may encourage drinking to overcome the shyness and isolation when it is time to relax. 'Creative writing requires a rich fantasy life; loners have rich fantasy lives: The ultimate loner lives in a prison of fantasy. Alcohol promotes fantasy. ' (Goodwin)

In this way, through Goodwin's perspective, writing and drinking may not have a cause-effect relationship but they are rather activities with common goals. Each complements the other.

The artist has often been portrayed as someone who is especially aware of the suffering of the world and needs to numb himself or herself to cope. Such a perspective allows an unlimited permit for self-indulgent excess leading to a premature ending, as a long list of writers that experienced it seem to prove.

In a study conducted by Nancy Andreasen (1987), a group of writers attending a creative writing workshop and a control group of non-writers (matched for age, gender, education and intelligence) were rated using the research diagnostic criteria (RDC). The writers had significantly higher levels of bipolar disorder and alcoholism than the control group, 24 out of 30 having experienced an affective disorder at some point in their life.

In addition, Felix Post's work underlines mostly the literary sphere and has concluded that, in contrast with people showing other kinds of creative achievement, creative writers are 'excessively prone to depressive and perhaps to manic disorders, as well as to alcoholism'. In a study focusing on those writing poetry, fiction and plays, Post found evidence of psychopathology in the biographies of 93 out of 100 individuals.

These studies point to a link between creative verbal or written, for that matter, ability and effectiveness, as well as related psychopathology, and this might be the underlying basis that links creativity and alcohol dependence.

Whether they argue for or against it, theories regarding the nature of the relationship between alcohol consumption and creativity have been circulating not only in psychology but around literature as well, for some time in recent history. And the fact that there might be a connection between the two seems to become rather undeniable.

This made Thomas Dardis ask the question of whether alcoholism is the American writer's disease, as most of the examples come from the New World (William Faulkner, Eugene O'Neill, Raymond Carver, Edgar Allan Poe, Ernest Hemingway, Scott F. Fitzgerald, Raymond Chandler etc.). While that might be in a way true, we can still discover cases of heavy drinking creative minds from outside the American soil as well, as James Joyce, Charles Baudelaire and Dylan Marlais Thomas demonstrate.

The world of art in general has provided us with an impressive number of binge drinkers that proved at the same time to be very prolific creative minds, from a variety of domains. Besides writers, there were painters, musicians and many others. (Charles Cros, Vincent Van Gogh, 
Beethoven, composer Modest Musorgski). This might be what gave birth in the first place to the idea that links between alcohol consumption and increased creativity can be found.

From the great Latin and Greek poets to the contemporary post modernists, drinking has been advocated whether as the opener of "the windows of the soul' (Dardis), an 'ecstasy of the mind." (Jack Kerouac) or considered a source of destructive force pressed upon the artist's talent, which will eventually diminish it completely ending his or her writing career.

There is a belief that creative individuals are expected to have a significant flaw in their character and that this is an integral part of their creativity. The leading Roman lyric poet, during the time of Augustus, Horace, believed, for example, that the writer has something of a tradition to uphold, as Homer himself was a great drinker: 'Ever since Bacchus recruited unhinged poets [...] the delightful muses have regularly reeked of wine in the morning'. (Dardis)

Long after that came William Faulkner's famous 'Civilization begins with distillation' and his confidence to his very end that his extraordinary powers of creation derived from alcohol. Critics cannot agree on whether alcohol helped or hindered his writing, although many blame his efforts on the effects of his beloved corn whiskey. Still, during his 50 years of writing he produced 19 novels, scores of poems and short stories, and dozens of screenplays.

Some other writers were driven as well by the belief that alcohol improved their writing ability. For example, Fitzgerald felt that stories he wrote while sober seemed 'stupid' and 'all reasoned out, not felt'. (Goodwin, 187)

Discussing E. A. Poe, Charles Baudelaire once commented that alcohol had become a weapon 'to kill something inside himself, a worm that would not die', and gave binge drinking the status of a kind of psychological salve. So it is in a way unsurprisingly, as Olivia Laing takes notice, that "the theories writers tend to offer (when discussion addiction) lean more towards the symbolic than the sociological or scientific', The same applies to Saul Bellow observing John Berryman: "Inspiration contained a death threat. He would, as he wrote the things he had waited and prayed for, fall apart. Drink was a stabilizer. It somewhat reduced the fatal intensity." (Amis)

On the same note, the French poet, phrased, again speaking on behalf of the intoxication, that alcoholic beverages have the feature of increasing the personality of 'the thinking being', and even goes to the lengths of saying that a combination of substances will automatically result in a 'poetic overstimulation' (Baudelaire) of the individual, being the proof of his brilliance. He believed that intoxication was essential to creativity (his famous dictum- 'always be drunk'). Nietzsche agreed with the idea, stating that 'for art to exist, for any sort of aesthetic society or perception to exist, a certain physiological precondition is indispensable: intoxication'. (Goodwin, 149),

The connection between drinking and achieving an alternative perspective ('the liberating infusion of whiskey') in modernist literature has also been noted by Thomas B. Gilmore. 'If two of the leading characteristics of modernism are a radical dissatisfaction with commonplace reality and a consequent attempt to undermine conventional reality by greatly altering traditional states of consciousness,' he notes, 'the fundamental challenge to and ruptures of these states offered by heavy drinking may seem desirable from a modernist viewpoint' (170)

There are many records of writers commenting on their use of alcohol, stating that it helped them to relax after an intense period of work. If James and Martin Amis do not get to the essential reason, in their works, why so many writers drink, they did manage to capture at least many of the author-drinkers' routines. James Joyce, for instance, only drank at night. "He engaged in excess with considerable prudence," biographer Richard Ellmann sustains. But maybe the best example is Ernest Hemingway, a close friend of Joyce, who had a regular routine. Each day he would get up early, write in the morning, fish or hunt in the afternoon and drink to relax and unwind in the evening. He also preached that 'a man does not exist until he is drunk'. Both he and William Faulkner said that they used alcohol to help them stop writing as well, to switch off the creative process.

Jack London applies a pattern, as well, when it comes to his drinking, confessing to something that reminds of a ritual: "I was carrying a beautiful alcoholic conflagration around with me. The 
thing fed on its own heat and flamed the fiercer. There was no time, in all my waking time, that I didn't want a drink. I began to anticipate the completion of my daily thousand words by taking a drink when only five hundred words were written. It was not long until I prefaced the beginning of the thousand words with a drink." (Crowley)

Alcohol may give writers confidence and help them to overcome what Georges Simenon called 'stage fright': the doubts about their ability to write and the quality of their work.

Another great advocator of the alcoholic aid is the German writer E.T.A. Hoffmann, who makes a classification of beverages according to the type of artistic work one desires to produce. For example, for something comedic, he instructs the use of the light Champagne, for the religious, the bitter Rhin and Jurancon and for the heroic creations, Bourgogne seems to facilitate their solemnness. The question of whether or not alcohol inspired Hoffmann creatively has long been a major focus for critics while trying to assess the relationship between the writer's drinking and his status as an artist.

On the other hand, there are opposed opinions that focus more on the negative effects of alcohol consumption regarding the creative process. Some of them emphasize the end results of a lifetime of binge drinking, such as suicidal thoughts or attempts, some even successful, depression, early deaths caused by diseases related to alcohol consumption or creative impotence followed by career endings. In addition to this, some, more contemporary authors, have agreed with Stephen King, believing that 'a writer who drinks carefully is probably a better writer'. (Goodwin, 187)

One of the fiercest opposition came from C. Sykes, who oddly in a way, shared a friendship with a drinking James Joyce. He strongly believes that heavy drinkers are incapable of producing anything noteworthy. In addition to this opinion comes another one, somewhat on the same level of opposition, C. Connolly's. He notes that 'alcoholism is the enemy of art and the curse of western civilization'. (Dardis) To complete this picture we might consider the cases of Raymond Carver or Malcolm Lowry, both writers who managed to produce their most appreciated and considered to be the greatest literary works only after reaching complete sobriety. Furthermore, the latter one created his best writing, 'Under the Volcano', while living in a hut in Canada. His writing output before and after this period was frequently described by critics as incoherent, while the writer himself was depicted as being unreliable, self-centred, sloppy and insecure at that particular time.

The issues surrounding alcohol and intoxication were exploited to portray Hoffmann, for example, and his work, negatively throughout the nineteenth century. It seems that critics tended to be reluctant to suggest that Hoffmann's imagination was fuelled by wine and punch.

To Goodwin, as well, nonetheless, alcohol is not just a harmless stimulus to creativity. $\mathrm{He}$ points to the obvious fact that a man may use it self-destructively, as Fitzgerald is considered to have done. ("First you take a drink, then the drink takes a drink, then the drink takes you").

Negative comments came from somewhat unexpected sources as well. Such is the case of Hemingway getting on his rather high horse when discussing Fitzgerald's ruinous drinking habits:

In this way his opinion seems to have switched from the initial famous "You're a rummy, but no more than most good writers are," addressed to his friend, to "It was hard to accept him as a drunkard, since he was affected by such minute quantities of alcohol. In Europe then we thought of wine as something healthy and normal as food and also as a great giver of happiness and well-being and delight. . . . I would not have thought of eating a meal without drinking wine or cider or beer ... and it had never occurred to me that sharing a few bottles of fairly light, dry, white Macon could cause chemical changes in Scott that would turn him into a fool." (Amis)

Dardis blames alcoholism for the 'sad and premature loss of creativity' (6) that plagued his subjects, and Kazin, discussing Faulkner, writes: 'Some of the side experiences were alcoholic exhaustion, DT's, whiskey ulcers, electroshock therapy, the many nicks and gashes in his head, broken ribs, falling downstairs, falls from horses, broken vertebrae, sweats, shakes, organic damage, fibrillation, blackouts'.

Vidal concludes perfectly this wave of opposition stating that "[h]eavy drinking stopped Hemingway from writing anything of value in his later years; killed Fitzgerald at forty-four; turned 
the William Faulkner of 'As I Lay Dying' into a fable" (276).. He continues by further stating that "after all, some writers do dry up creatively without ever tasting a drop. But it is a fact that a high percentage of the major American writers of this century have suffered from alcoholism. The creative decline usually begins in the writer's late thirties. . . (T)his was not the case with the great English and European writers of the last century, who did not drink alcoholically and who continued to write powerfully long beyond the modern American ones: . . Dostoevsky wrote 'The Brothers Karamazov` at fifty-nine and . . Thomas Mann wrote `Doctor Faustus`at seventy-two”. (47)

\section{LITERARY PERSPECTIVES ON ALCOHOL USE}

In this way, Beveridge \& Yorston (1999) point out that writers and artists have often seen the role of alcohol very differently. Alcohol has been a part of religious practices and customs for thousands of years and is often seen as an agent of 'mystical transport' (Edwards) and although from a medical point of view it does nothing but harm, its consumption has been regarded also as a means of spiritual exploration and a way of seeking enlightenment.

As Laing also shows, alcohol seems to be a catalyst for something difficult to categorize, a secret, a pressure, a private tragedy, serving as both a release and an ecstasy. "I was beginning to think," she notes, as her quest on the footsteps of the brilliant but alcoholic writers deepens, "that drinking might be a way of disappearing from the world."

Thus, it rather seems that alcohol can ease the pain of the writer's lot. To write is to be lonely, Goodwin says, but alcohol assuages loneliness. To write demands intense concentration, but drink relaxes, emancipating the writer from "the tyranny of mind and memory." (Goodwin)

Further sustaining the already well known idea of the flawed artist, Dr. Goodwin states that, in a way, all the writers analysed in his book can be considered schizophrenic. Most had radical mood shifts when drinking. The examples that seem to portray best this idea are those of Fitzgerald, who would check his breath after one drink to make certain it wasn't offensive. But given a few more and he seemed to go out of his way to do so.

Also, Hemingway's mood shifts were frequent, and his fantasy life was so rich that during one well-documented visit to New York, he often addressed imaginary audiences, to the astonishment of his companions.

Furthermore, immoral behaviour enforced by writers has been seen as a symbol of rebellion, and drinking has often formed an integral part of literary scenes, where it has acted as 'a symbol of defiance against contemporary values'. (Crowley) Then there is the belief that some must experience degradation to produce great work. The first example of this that comes to mind is Charles Bukowski, who, in addition to his poetry, wrote a string of semiautobiographical novels about his impoverished early life and his time spent drinking heavily, in a way, as a result to it.

Thus, the drinking writer has been understood as one who responds to the existential despair with a raised glass, who trespasses the bounds of politeness and suffocating traditionalism, who courts disaster as a discharge from his consuming genius, who channels his energies into drink, producing a literature soaked with "the power to map the more difficult regions of human experience" (Laing). In a post-war climate characterized by disillusionment, trauma, and chaos, in the wake of 'a sacrifice for which there is no recompense' (Armstrong, 18), the modernist writer's only suitable response is to drink himself out of sobriety. To further sustain this idea, Hemingway once wrote, "modern life is often a mechanical oppression and liquor is the only mechanical relief."

Modernist writers, by producing a literature that idealized intoxication, making the 'drunk' carrying the weight of an 'anti-Puritan rebel' (Crowley, 174), effectively made binge drinking a cultural requirement for any writer who aimed for fame and success, who desired a literary image in any way close to that of a Hemingway or a Fitzgerald.

The association of writing with alcohol consumption has been a powerful one, so much that it determined Newlove to write: "Before I got sober, I feared that public knowledge that I was a recovering alcoholic would dim my chances as a writer, perhaps even lend me a leprous cast among 
my writing peers, the scarlet label SOBER stamped on my brow. 'You mean he doesn't drink ever? That must have an awful effect on his writing, don't you think?"' (Crowley, 112). He manages to emphasise here two major facts: that his sobriety might alienate him from a literary culture in which alcohol consumption plays a prominent role and that the writing he produces would suffer (or be perceived to be suffering) without the aid of drink. 'My greatest difficulty was entertaining some thought of a Higher Power I might speak to in my heart. All my saints were dead drunks'. (Crowley, 106). This might paradoxically underline the fact that the modernists' drinking practices were in a way propagated.

Time and time again, Crowley asserts that beneath aesthetic and philosophical justifications of binges and benders lay desires for 'homosocial' bonding.

Thus, it seems obvious that alcohol served as a social aid among the modernist writers as well. It was the glue that bonded together the legion of expatriate talent that had gathered along Paris' Left Bank, for example. The cafes, bars and balls became rallying points for the brightest minds of the 'Lost Generation'. F. Scott Fitzgerald insanely drunk on champagne, Ezra Pound sipping absinthe, Gertrude Stein enjoying a fine red, James Joyce savouring scotch and Ford Maddox Ford sending back a brandy for the fourth time, is said to have been a well-known scene in these places, at that time. Decades later critics would try to explain the excessive drinking as an unnecessary evil that plagued the era but Fitzgerald begged to differ:

"Sometimes I wish I'd went through those good times stone cold sober so I could remember everything," he said, "but then again, if I had been sober the times probably wouldn't have been worth remembering." (Amis)

In 'Everyday Drinking', K. Amis also observes that for most of these writers, alcohol contributes to conviviality. It made socialising easier, connecting drinking with language use. Amis notes: "conversation, hilarity and drink are connected in a profoundly human, particularly intimate way." He goes further in demonstrating the closeness of the relationship by stating, from the binge drinker writer perspective, as Amis saw the consumption of alcohol and the production of literature as cross-pollinating and concentrated on drinking as his recurring subject in both fiction and nonfiction, that "the reason why I, and so many others, usually turn out to enjoy meeting such creatures is simply and obviously the co-presence of drink," (when discussing meeting strangers, potential writing material).

Herman Melville, "among the most ardent lovers" of alcohol according to his biographer, Andrew Delbanco, similarly linked drinking with amiable conversing. In a letter, he advised his friend, Nathaniel Hawthorne "to have ready a bottle of brandy because I always feel like drinking that heroic drink when we talk ontological heroics together." (Amis) (Samuel Johnson also associated brandy with the heroic. "He who aspires to be a hero must drink brandy," he famously stated.)

In addition, comes the poet and critic's, Clive James's, alternative. He sees alcohol as providing talented writers with release and relief from the demands of their craft. In 'Cultural Amnesia', he tries to explain: "The main reason a good writer needs a drink at the end of the day is the endless, finicky work of disarming the little booby traps that the language confronts him with as he advances."'(K. Amis) (Notice that he does not bother with the other writers, the mediocre ones, as if only "good" ones deserve that single reward each evening.)

In his memoir 'Experience', Martin Amis tries to understand his father Kingsley Amis's commitment to drinking and comes to a somewhat similar conclusion: "A writer's life is all anxiety and ambition - and ambition, here, is not readily distinguishable from anxiety; it is a part of your desire to do right by what talent you have. So some of us will be wanting a break from that, if we can manageably get it." While explanations like these have undeniable merit they could, very easily, we must acknowledge, with only slight modification, apply to scrupulous workers in any field of the modern society. 


\section{CONCLUSIONS}

A close analysis on the lives of many famous writers has revealed throughout time evidence of heavy alcohol consumption. This seems to have been accompanied by a mixture of mental illnesses, physical diseases, family breakdowns, suicides and/or premature deaths, combined with brilliant creative prolificacy that resulted in literary glory. Although, this issue has hardly been given the attention that it required, especially in the Romanian literature, due probably to the fact that it may still be considered a controversial subject to tackle, this paper manages to confirm some of the existent theories regarding the links that can be established between alcoholism and the creative flow. Thus, further studies are necessary in order to truly establish the nature of the connection between binge drinking and the creative mind, in order to confirm whether it can go beyond being coincidental.

\section{References}

[1] Amis, Kingsley. Everyday Drinking. Bloomsbury USA, 2008.

[2] Baudelaire, Charles. Paradisurile artificiale. Despre vin şi haşiş. Trans. Gabriela and Constantin Abăluță. ART classic, 2010.

[3] Behavior: The Writer's Vice. Web. Monday, Oct. 05, 1970.

[4] Crowley, John W. The White Logic: Alcoholism and Gender in American Modernist Fiction. Amherst: U of Massachusetts P, 1994.

[5] Dardis, Thomas. The Thirsty Muse: Alcohol and the American Writer. Houghton Mifflin Harcourt, 1989.

[6] Davies, J. B. The Myth of Addiction, 2nd ed. Amsterdam: Harwood Academic Publishers, 1997.

[7] Day, Ed and Iain Smith. Literary and biographical perspectives on substance use. Advances in Psychiatric Treatment, vol. 9, 2002.

[8] De Quincey, T. Confessions of an English Opium Eater. London: Penguin Book, 1986.

[9] Dutchman-Smith, Victoria. E. T. A. Hoffmann and Alcohol, Biography, Reception, and Art. Modern Humanities Research Association, 2009.

[10] Goodwin, D. W. Alcohol and the Writer. Kansas City: Andrews and McMeel, 1988.

[11]Laing, Olivia. The Trip to Echo Spring: On Writers and Drinking. Picador. Reprint edition. October 28, 2014.

[12] Post, F. Creativity and psychopathology. A study of 291 world-famous men. British Journal of Psychiatry, 1994.

[13]Post, F. Verbal creativity, depression and alcoholism. An investigation of one hundred American and British writers. British Journal of Psychiatry, 1996.

[14] Rodwan Jr., John G. A Drink-Man among Drink-Men. Rev. of Everyday Drinking by Kingsley Amis. Open Letters Monthly. Web. December, 2008.

[15] Sanderson, Caroline. Why Writer's Drink, By Olivia Laing, Rev. of The Trip to Echo Spring by Olivia Laing. Web. Saturday 10 August 2013.

[16] Ver Berkmoes, Ryan. Booze and the Muse, Why Writers and Alcohol Often Made a Creative but Ruinous Mix. American Medical Association, 1989. 